\title{
Analysis of the seasonal variation in biochemical composition of Daphnia magna Straus (Crustacea : Branchiopoda : Anomopoda) from an aerated wastewater stabilisation pond
}

\author{
H.-M. Cauchie ${ }^{1}$ \\ M.-F. Jaspar-Versali ${ }^{2}$ \\ L. Hoffmann ${ }^{3}$ \\ J.-P. Thomé1
}

Keywords : Daphnia magna, lipids, proteins, carotenoids, chitin, biochemical composition, waste stabilisation pond, aquaculture.

The biochemical composition of Daphnia magna Straus, the dominant planktonic crustacean of the waste stabilisation pond of Differdange (Grand-Duchy of Luxembourg), was quantitatively determined from October 1993 to July 1994. Over the sampling period, the average composition (mean \pm S.D.) was $271 \pm 64 \mathrm{mg}$ proteins. $\mathrm{g}^{-1}$ dry weight (DW), $100 \pm 28 \mathrm{mg} \mathrm{lipids.g^{-1 }}$ (DW), 96 $\pm 58 \mu \mathrm{g}$ carotenoids. $\mathrm{g}^{-1}$ (DW), $49 \pm 14 \mathrm{mg}$ chitin. $\mathrm{g}^{-1}$ (DW) and $125 \pm 78 \mathrm{mg}$ ash. $\mathrm{g}^{-1}(\mathrm{DW})$. The seasonal variations of the biochemical composition were related to several ecological variables (water temperature, dissolved oxygen concentration, $\mathrm{pH}$, water transparency, chlorophyll $a$ concentration and $D$. magna biomass). The chitin content was positively correlated to the water temperature as a result of the strong influence of this later variable on the moulting rate of the daphnids and, subsequently, on the chitin synthesis by these organisms. The carotenoid content was positively correlated to the water transparency as a result of their photoprotective role in daphnids. The fluctuations of the lipid, protein and ash levels in D. magna depended to the food availability. Despite a seasonal variation in the biochemical composition, $D$. magna appeared to have adequate lipid and protein levels to be used in aquaculture. Its carotenoid content is similar to fish meals used to color salmonid flesh and these organisms could be used for this purpose. The prospect of using $D$. magna for chitin extraction is worth considering with respect to its significant chitin content, especially if highly valuable applications are aimed.

Analyse de la variation saisonnière de la composition biochimique de Daphnia magna Straus (Crustacea : Branchiopoda : Anomopoda) vivant dans un étang de lagunage aéré

Mots-clés : Daphnia magna, lipides, protéines, caroténoïdes, chitine, composition biochimique, étang de lagunage, aquaculture.

La composition biochimique de Daphnia magna Straus, le crustacé planctonique dominant dans l'étang de lagunage de Differdange (Grand-Duché de Luxembourg), a été déterminée quantitativement d'octobre 1993 à juillet 1994. Pendant cette période, la composition moyenne a été caractérisée par des teneurs s'élevant à (moyenne \pm écart-type) $271 \pm 64 \mathrm{mg}$ protéines. $\mathrm{g}^{-1}$ masse sèche (MS), $100 \pm 28 \mathrm{mg}$ lipids.g $\mathrm{g}^{-1}$ (MS), $96 \pm 58 \mu \mathrm{g}$ caroténoïdes. $\mathrm{g}^{-1}$ (MS), $49 \pm 14 \mathrm{mg}$ chitine. $\mathrm{g}^{-1}$ (MS) and $125 \pm 78 \mathrm{mg}$ cendres. $\mathrm{g}^{-}$ 1 (MS). Les variations saisonnières de la composition chimique des daphnies ont été mises en relation avec plusieurs variables écologiques (température de l'eau, concentration en oxygène dissous, $\mathrm{pH}$, transparence de l'eau, concentration en chlorophylle $a$ et biomasse de $D$. magna). La teneur en chitine s'est avérée positivement corrélée à la température de l'eau en raison de l'influence marquée de celle-ci sur le rythme de mue des daphnies et, par conséquent, sur la synthèse de chitine chez ces organismes. Le contenu en caroténoïdes s'est révélé positivement corrélé à la transparence de l'eau en raison du rôle de photoprotection de ces pigments. Les fluctuations des teneurs en lipides, protéines et cendres chez $D$. magna dépendent de la disponibilité en nourriture dans le milieu. Malgré les variations saisonnières de sa composition biochimique, $D$. magna s'avère avoir une teneur en lipides et en protéines adéquate pour son utilisation en aquaculture. Sa teneur en caroténoïdes est similaire à celle des régimes utilisés pour colorer la chair des salmonidés. Les daphnies peuvent donc être utilisées à cet effet. La perspective d'utilisation de $D$. magna comme source commerciale de chitine est particulièrement prometteuse compte tenu de sa teneur en chitine, en particulier si on envisage des applications à haute valeur ajoutée.

1. Université de Liège, Institut de Zoologie, Laboratoire d'Ecologie Animale et d'Ecotoxicologie, quai Van Beneden, 22, B-4020 Liège, Belgique.

2. Université de Liège, Institut de Chimie, Groupe de Recherche "Chitin-Chitosan", B6, Sart-Tilman, B-4000 Liège, Belgique.

3. Université de Liège, Institut de Botanique, Laboratoire d'Algologie, de Mycologie et de Systématique Expérimentale, B22, Sart Tilman, B4000 Liège, Belgique. 


\section{Introduction}

Due to its ability to survive in highly eutrophic conditions, Daphnia magna Straus is commonly found in waste stabilisation ponds (Dinges 1973, Dor et al. 1987, Hathaway \& Stefan 1995). In such ponds, this planktonic species is thought to improve the biological quality of the effluent by extensive grazing on suspended bacteria, algae and detritus. The standing crops of Daphnia magna are often considerable, notably because of the absence of predators, and its annual production reach from 100 to $500 \mathrm{~g}$ dry weight. $\mathrm{m}^{-3}$. year ${ }^{-1}$ in some facilities (Sevrin-Reyssac 1992, Cauchie et al. 1995). At present, these crustaceans are mainly used, alive or preserved, as food for fish in aquaculture (Edwards \& Pullin 1990, Sevrin-Reyssac 1992).

In 1988, Daphnia magna was introduced in the waste stabilisation pond of Differdange (Grand-Duchy of Luxembourg) in order to enhance the wastewater treatment. Since 1992, large amounts of daphnids have been regularly harvested in spring and in summer to be sold as aquarium fish food. The aim of this study was to determine the seasonal variation of the daphnid biochemical composition in order to evaluate the prospect of using them for commercial applications such as fish meal preparation or chitin extraction. Chitin, poly- $\beta-1,4-D$-glucosamine, and its deacetylated derivative, chitosan, have recently found numerous applications in various fields with a great added value, including pharmaceutical and biomedical sectors, cosmetics and wastewater treatment (Muzzarelli 1996). The basic biochemical composition of Daphnia magna (proteins, lipids, chitin, ash and carotenoids) was investigated from October 1993 to July 1994. The seasonal variation of the composition was analysed in relation to physico-chemical variables in a redundancy analysis.

\section{Material and methods}

\subsection{Site description}

The studied waste stabilisation pond is located near the town of Differdange in the Grand-Duchy of Luxembourg $\left(49^{\circ} 32^{\prime} \mathrm{N}-5^{\circ} 55^{\prime} \mathrm{E}\right)$. It is a roughly rectangular pond $\left(59,000 \mathrm{~m}^{2}, 2.3 \mathrm{~m}\right.$ mean depth) equipped with two surface aerators ( $35 \mathrm{~kW}$ capacity each) collecting the waste waters of the town $(15,000$ inhabitant-equivalents) after primary treatment. In terms of biomass, the zooplankton community is dominated by crustaceans, namely the anomopod Daphnia magna (Cauchie et al. 1995).

\subsection{Biochemical analysis of Daphnia magna}

From July 1993 to June 1994, zooplankton samples were collected on fourteen occasions. Crustaceans were concentrated by pumping and filtering large volumes of water over a Nylon net (mesh size $=100 \mu \mathrm{m})$. At the laboratory, $2 \mathrm{~mm}$ long $D$. magna specimens were selected, killed with $4 \%$ formaldehyde and immediately rinsed during 10 minutes in distilled water. In order to prevent the alteration of the carotenoids, the daphnids were freeze-dried in the dark. The samples were kept at $4^{\circ} \mathrm{C}$ until biochemical analysis.

For protein and chitin analyses, the freeze-dried material was first decalcifided by means of $\mathrm{HCl} 0.5 \mathrm{~N} \mathrm{du}$ ring 4 hours. Proteins were then extracted in the residue using a $\mathrm{NaOH} 0.5 \mathrm{~N}$ solution at $100^{\circ} \mathrm{C}$ for 6 hours and were assayed by the Lowry method (Lowry et al. 1951) as modified by Schacterle \& Pollack (1973). The amount of protein removed by the $\mathrm{HCl}$ treatment was estimated spectrophotometrically in $\mathrm{HCl}$ extracts by the method described by Scopes (1974). Total protein content was estimated by adding $\mathrm{HCl}$-soluble protein estimates to $\mathrm{NaOH}$-soluble protein concentrations. Chitin was enzymatically determined according to Jeuniaux $(1963,1965)$ in the insoluble residue remaining after the successive $\mathrm{HCl}$ and $\mathrm{NaOH}$ treatments. The residue was incubated in a solution of purified chitinase (Sigma 6137; $1 \mathrm{mg} \cdot \mathrm{ml}^{-1}$ distilled water) at $37^{\circ} \mathrm{C}$ during 8 hours. The supernatant was then incubated in a solution of $\mathrm{N}$-acetylglucosaminidase (lobster serum diluted ten times) during 4 hours at $37^{\circ} \mathrm{C}$. The $\mathrm{N}$-acetylglucosamine monomers liberated by the enzymatic hydrolysis of chitin were measured by the colorimetric method of Reissig et al. (1955).

Total lipid extraction was performed on freeze-dried daphnids using a chloroform : methanol $(2: 1) \mathrm{mix}$ (Bligh \& Dyer 1959). The chloroform layer was separated and dried at $50^{\circ} \mathrm{C}$ under dry nitrogen flow. Lipids were assayed colorimetrically in the residues using the sulfophospho-vanilline method (Barnes \& Blackstock 1973).

The total carotenoid content of the daphnids was determined following a method similar to that of Herring (1968a). The pigments were extracted in $90 \%$ ethanol during 24 hours at $20^{\circ} \mathrm{C}$ in the dark. Absorption scans of the supernatant were performed between 350 and $700 \mathrm{~nm}$ with a precision of $1 \mathrm{~nm}$ using a Beckman DU 650 spectrophotometer. The total carotenoid content was calculated using the average OD of the supernatant between 450 and $480 \mathrm{~nm}$ assuming an extinction coefficient of 2,500 as an approximate value for carotenoids (Zagalsky et al. 1967). The wavelengths corresponding to maximal absorbance were identify in or- 
der to determine, if possible, the nature of the carotenoids on the basis of their specific absorbance profiles in $90 \%$ ethanol (Davies 1976).

The ash content was estimated by determining the weight loss after the incineration of freeze-dried material at $550^{\circ} \mathrm{C}$ for 24 hours in a muffle furnace. At this temperature, $\mathrm{CaCO}_{3}$ sublimation is negligible (Paine 1971).

\subsection{Ecological variables}

Ecological variables were measured twice a month from October 1993 to July 1994 . Temperature, dissolved oxygen concentration, $\mathrm{pH}$ and water transparency were measured using a WTW oximeter equipped with an oxygen probe and a thermistor, a WTW pHmeter and a Secchi disk, respectively. Chlorophyll $a$ concentrations were measured using the methods described by Lorezen (1967). $100 \mathrm{ml}$ of pond water were filtered through a Gelman Nylon membrane (pore size = $0.45 \mu \mathrm{m}$ ) and acetone (90\%) was used as solvent. Zooplankton samples were collected using a 3-liter Van Dorn bottle, filtered on Nylon net (mesh size $=80$ $\mu \mathrm{m}$ ) and preserved in $4 \%$ formaldehyde. Daphnia magna was enumerated and measured to the nearest 50 $\mu \mathrm{m}$ using a dissecting microscope equipped with a micrometer. Its biomass was calculated using lengthweight regressions established by Dumont et al. (1975).

\subsection{Data analysis}

The biochemical composition of D. magna was related to the ecological variables in a Redundancy analysis (RA) using the program CANOCO for Windows (ter Braak \& Smilauer 1998). Ecological variables were standardised to zero mean and unit variance (ter Braak \& Prentice 1988). A Monte-Carlo permutation test was realised to determine whether the biochemical variables were significantly related to the ecological variables (Verdonschot \& ter Braak 1994).

\section{Results}

\subsection{Biochemical composition of Daphnia magna}

The variations in the biochemical composition of $D$. magna are presented in Fig. 1. The total lipid content of D. magna varied between 101 and $171{\mathrm{mg} . \mathrm{g}^{-1}}$ (DW) from October to December 1993 and between 65 to $107 \mathrm{mg} \cdot \mathrm{g}^{-1}$ (DW) from February to July. Protein content increased steeply from 186 to $334 \mathrm{mg} . \mathrm{g}^{-1}$ (DW) from October to December 1993. From February to July 1994, the protein content varied between 217 and $396 \mathrm{mg} \cdot \mathrm{g}^{-1}$ (DW).
From October to March, the chitin level of D. magna varied, on the whole, from 30 to $50 \mathrm{mg} \cdot \mathrm{g}^{-1}$ (DW). It increased then steeply in April and reached $67 \mathrm{mg} \cdot \mathrm{g}^{-1}(\mathrm{DW})$ at the beginning of May. It varied between 60 and $70 \mathrm{mg} \cdot \mathrm{g}^{-1}$ (DW) in June and July.

Carotenoid level in D. magna fell from $156 \mu \mathrm{g} \cdot \mathrm{g}^{-1}$ (DW) in October to $63 \mu \mathrm{g} . \mathrm{g}^{-1}$ (DW) at the beginning of December. In February and March, it was lower than $50 \mu \mathrm{g} \cdot \mathrm{g}^{-1}$ (DW). A peak of carotenoid content was then observed in May with a maximum value of 246 $\mu \mathrm{g} \cdot \mathrm{g}^{-1}$ (DW). On the fourteen sampling dates, the maximum absorbance of the ethanol extract lay between 460 and $466 \mathrm{~nm}$.

The ash content of Daphnia magna was quite low (<100 mg.g ${ }^{-1}$ (DW)) from October to December 1993. In 1994, it increased steeply at the end of April to reach a maximum value of $327 \mathrm{mg}^{-1} \mathrm{~g}^{-1}$ (DW). From the end of May to the end of July, the ash content varied from 100 to $200 \mathrm{mg} \cdot \mathrm{g}^{-1}$ (DW).

\subsection{Ecological variables}

Variations in the ecological variables are shown in Fig. 2. Water temperature varied from $1.7^{\circ} \mathrm{C}$ in December to $25.2^{\circ} \mathrm{C}$ in July. Dissolved oxygen concentration was higher than $8 \mathrm{mg} \mathrm{O} \mathrm{O}_{2} \cdot \mathrm{l}^{-1}$ from December to March and then sharply decreased under $4 \mathrm{mg} \mathrm{O}_{2} \cdot \mathrm{l}^{-1}$ at the beginning of May. In June, a peak of oxygen was observed with a maximum value of $10 \mathrm{mg} \mathrm{O} \cdot \mathrm{O}_{2} \cdot \mathrm{l}^{-1} \mathrm{pH}$ was quite constant over the sampled period, ranging from 7.8 to 9.0 . Maximum values were observed in March $(\mathrm{pH}=9.0)$ and in June $(\mathrm{pH}=8.6)$. Highest water clarity was observed in January and May when the disk was still visible below a depth of 2 meters. Chlorophyll $a$ concentration was relatively low ( $<5 \mathrm{mg} \cdot \mathrm{m}^{-3}$ ) during the sampling period, except in March and in June when it reached 283 and 160 mg. $\mathrm{m}^{-3}$, respectively. Daphnia magna biomass decreased from about $0.9 \mathrm{~g}$ (DW). $\mathrm{m}^{-3}$ in November to virtually zero in December. It remained nil until the end of February. At the beginning of March, D. magna biomass peaked to $1.7 \mathrm{~g}$ (DW). $\mathrm{m}^{-3}$. From March to July, four successive peaks of daphnid biomass were observed. Maximum values ranged from 1.4 to $1.7 \mathrm{~g}$ (DW). $\mathrm{m}^{-3}$

\subsection{Relationships between biochemical and ecolo- gical variables}

On the basis of the RA ordination (Fig. 3), several correlations were detected between biochemical and ecological variables. It was inferred that the chitin content and the carotenoid content were correlated with the water temperature and the water transparency, respectively. The chlorophyll $a$ concentration, dissol- 

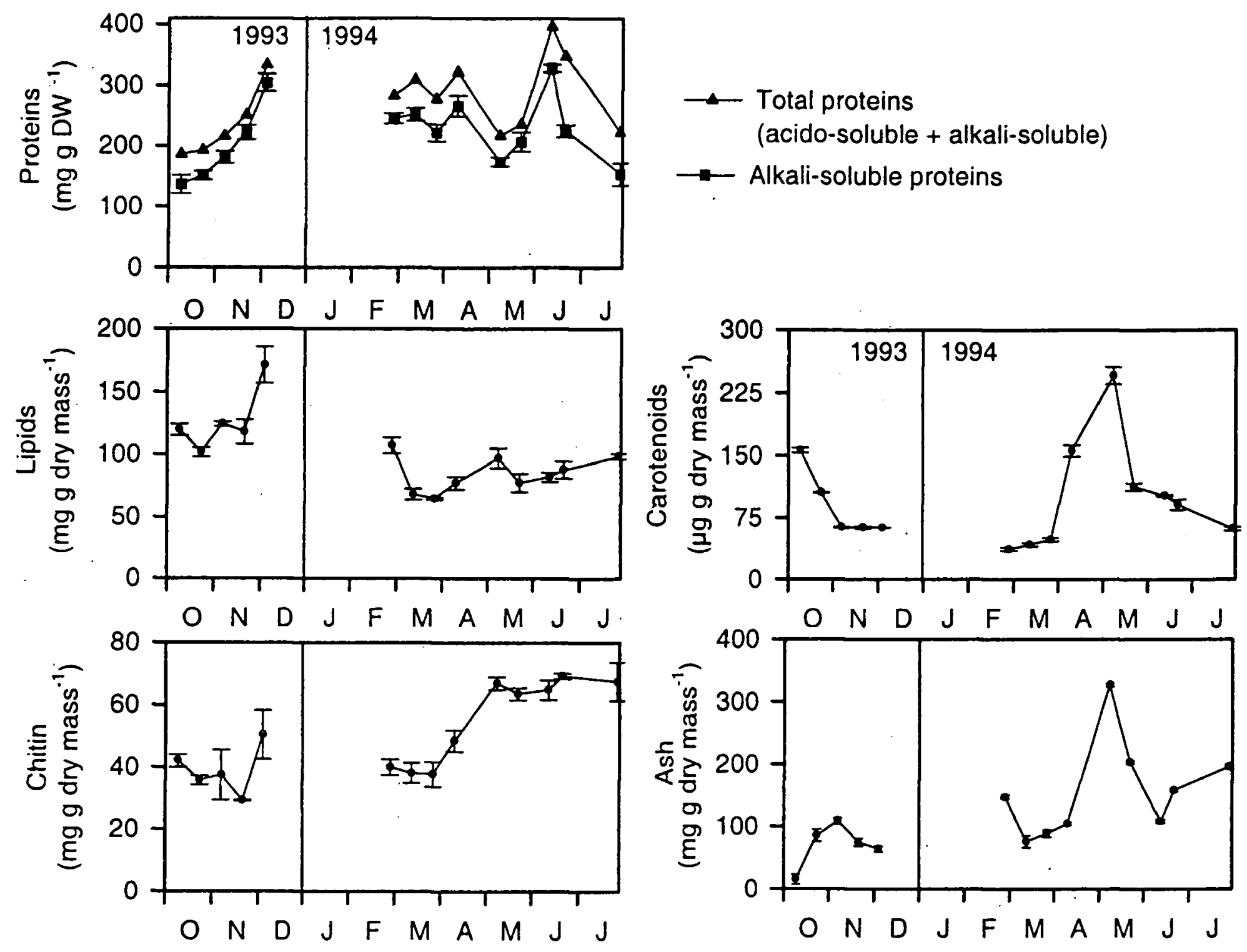

Fig. 1. Seasonal variations of the biochemical composition of Daphnia magna in the waste stabilisation pond of Differdange from October 1993 to July 1994.

Fig. 1. Variations saisonnières de la composition biochimique de Daphnia magna dans l'étang de lagunage de Differdange d'octobre 1993 à juillet 1994.

ved oxygen concentration and $\mathrm{pH}$ were positively correlated with each other and with the protein content. On the other hand, these three variables were negatively correlated with the water transparency. The lipid content was negatively correlated with $D$. magna biomass. The ash content was not clearly correlated with any of the studied variables.

\section{Discussion}

Lipid levels measured in D. magna at Differdange are, on the whole, in good agreement with other data found in the literature (Table 1). On the contrary, protein levels are globally lower than those measured by Blazka (1966), McKee \& Knowlês (1987) and to a certain extend by Elendt (1989). Differences in methodology may account for this divergence. Blazka (1966) used the Kjeldahl method to determine proteins. This method indeed lacks specificity since it assays not only protein-nitrogen but total organic nitrogen. The total protein content may thus be overestimated. McKee \& Knowles (1987) did not measure the initial dry mass but estimated it from summation of the residual mass after all the extraction and the concentration of the assayed compounds. This means that biomolecules such as some soluble sugars and ions that have been extracted but not assayed were not accounted for in the calculation of the dry mass. The total dry mass was thus presumably underestimated and the protein content was overestimated. Elendt (1989) used the method of Bradford (1975) which often yields results comparable to those obtained by the method of Lowry. However, the dependence of the Bradford procedure on protein amino acid composition (Dunn 1993) can sometimes produce significantly different results from those obtained with the Lowry method. 

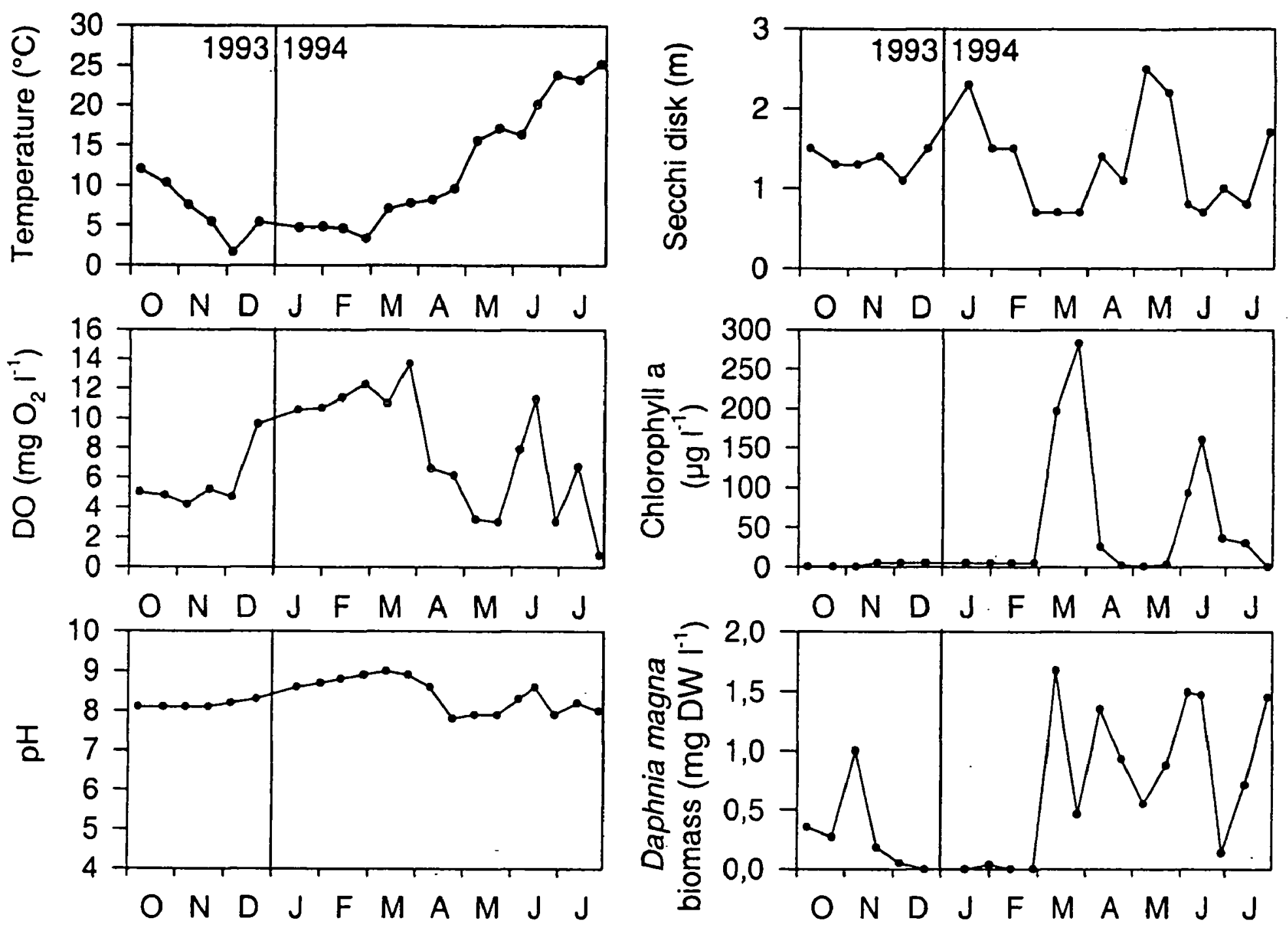

Fig. 2. Seasonal variations in water temperature, dissolved oxygen concentration (DO), pH, water transparency (Secchi disk), chlorophyll $a$ concentration and Daphnia magna biomass in the waste stabilisation pond of Differdange from October 1993 to July 1994.

Fig. 2. Variations saisonnières de la température de l'eau, de la concentration en oxygène dissous (DO), du pH, de la transparence de l'eau (disque de Secchi), de la concentration en chlorophylle $a$ et de la biomasse de Daphnia magna dans l'étang de lagunage de Differdange d'octobre 1993 à juillet 1994.

Table 1. Protein, lipid and carotenoid levels in Daphnia magna.

Tableau 1. Teneurs en protéines, lipides et caroténoïdes de Daphnia magna.

\begin{tabular}{lccc}
\hline References & $\begin{array}{c}\text { Proteins } \\
\left(\mathrm{mg} \cdot \mathrm{g}^{-1}\right)\end{array}$ & $\begin{array}{c}\text { Lipids } \\
\left(\mathrm{mg} \cdot \mathrm{g}^{-1}\right)\end{array}$ & $\begin{array}{c}\text { Carotenoids } \\
\left(\mu \mathrm{g} \cdot \mathrm{g}^{-1}\right)\end{array}$ \\
\hline Farkas, 1958* & 223 & 346 & - \\
Blazka, 1966* & 680 & 131 & - \\
Czeczuga, 1984 & - & - & 4 \\
Partali et al., 1985 & - & - & $25-237$ \\
McKee \& Knowles, 1987 & $477-620$ & $64-179$ & - \\
Elendt, 1989 & $263-566$ & $57-128$ & - \\
De Meester \& Beenaerts, 1993 & - & - & $250-457$ \\
This study & $186-397$ & $65-171$ & $37-246$ \\
\hline
\end{tabular}

* cited in Vijverberg \& Frank, 1975 

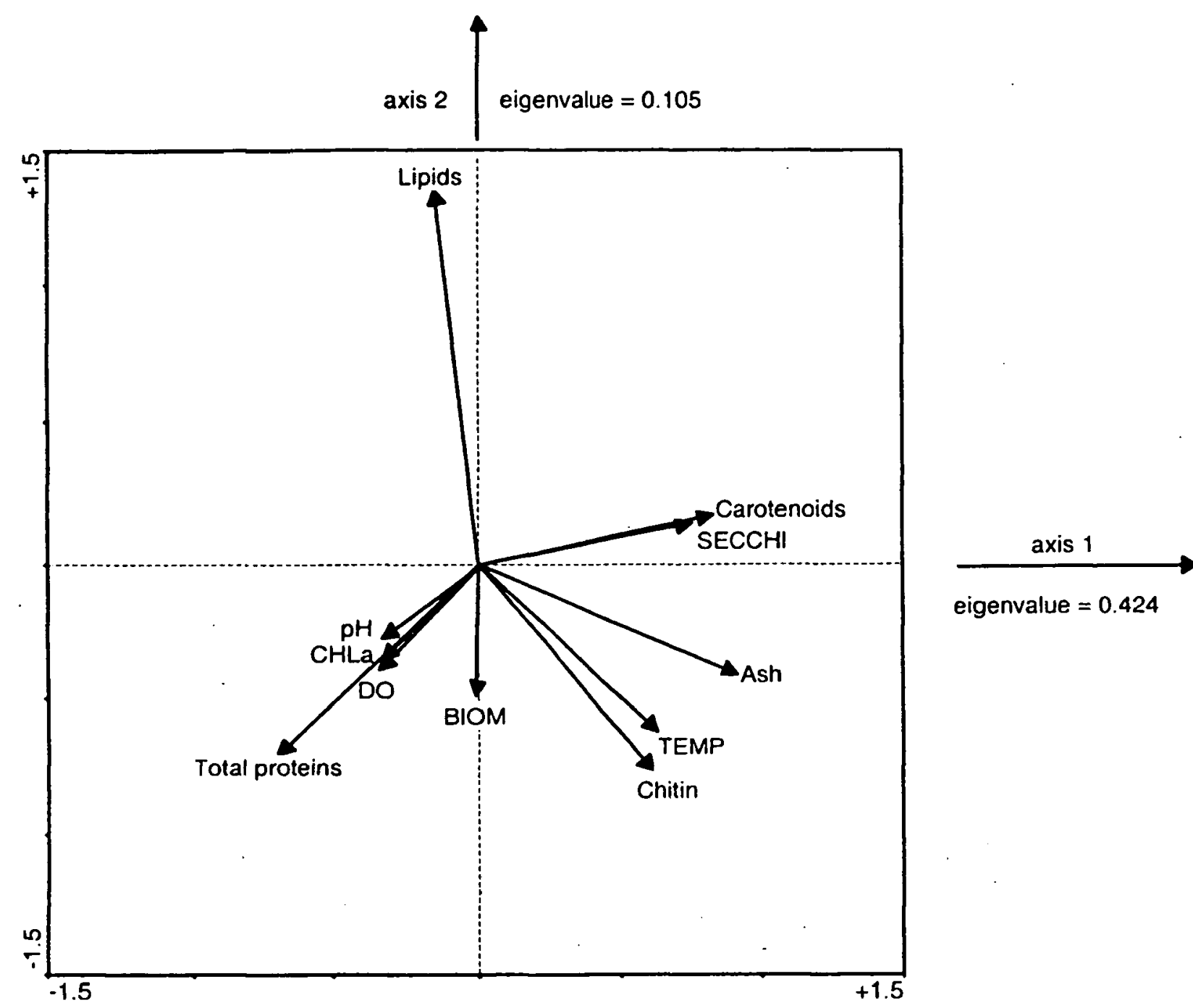

Fig. 3. Redundancy analysis ordination diagram of biochemical (in lower case letters) and ecological variables (in upper case letters). Abbreviations : TEMP = water temperature ; $\mathrm{DO}=$ dissolved oxygen concentration ; SECCHI = water transparency measured with the Secchi disk; CHLa $=$ chlorophyll $a$ concentration $; \mathrm{BIOM}$ = Daphnia magna biomass.

Fig. 3. Diagramme de l'ordination par analyse de redondance des variables biochimiques (lettres minuscules) et écologiques (lettres majuscules). Abréviations : TEMP = température de l'eau ; DO = concentration en oxygène dissous ; SECCHI = transparence de l'eau mesurée à l'aide du disque de Secchi ; CHLa = concentration en chlorophylle $a ;$ BIOM = biomasse de Daphnia magna.

In cladocerans, lipids and proteins are considered to be good indicators of the nutritive state (Tessier \& Goulden 1982, Guisande et al. 1991). At low food concentration, lipid reserves, mainly triacylglycerides, are metabolised while proteins are only catabolised under severe starvation (Elendt 1989). Under laboratory conditions, the lipid content of $D$. magna ranges from 128 to $197 \mathrm{mg}^{-1} \mathrm{~g}^{-1}$ (DW) in well-fed animals and drops to about $60 \mathrm{mg}^{-\mathrm{g}^{-1}}$ (DW) in starved, hatching or senescent specimens (McKee \& Knowles 1987, Elendt 1989). The ash content is also used as an indicator of the zooplankton nutritive state (Lemcke \& Lampert 1975, Berberovic 1990). Under starvation, the relative ash content has been found to increase because the absolute ash content remains constant while the total dry weight is decreasing as a result of lipid and protein catabolism.
In the waste stabilisation pond of Differdange, high lipid levels and low ash levels were recorded in daphnids during autumn. This indicates that, despite the absence of algae, daphnids were not starved and probably fed on other food sources such as bacteria, protozoa or detritus (Porter et al. 1983, Jürgens 1994). On the other hand, the lipid content was low (<100 mg.g g $^{-1}$ (DW)) from February to July. Lipids were particularly depressed when chlorophyll $a$ and daphnid biomass were high in March and June. This is probably due to the increasing reproductive rate during daphnids blooms. The lipid level of females is indeed lowered when releasing lipid-rich neonates (Elendt 1989). Contrary to lipids, proteins was positively correlated with algal food resources. The depression of proteins and the steep increase of ashes in May probably highlighted a real depression in the food resources 
which led to starvation and a steep decrease of $D . m a-$ gna biomass.

Data about chitin content in crustaceans are scarce and, regarding anomopods, seem to be restricted to our study. Comparisons with chitin levels in other branchiopods have been made elsewhere (Cauchie et al. 1997). Contrary to proteins, lipids or carotenoids, chitin is localised nowhere else than in the cuticle. Therefore, at the individual level, an increasing chitin content indicates that the animal is in pre- or postmoulting stage. Considering that moulting is not synchronised in the population, an increasing chitin level in our samples reflects an increase of the proportion of animals that are in a moulting stage. As the moulting frequency is closely related to temperature (Bottrell 1975), this may explain why a positive correlation was found between chitin level in Daphnia magna and temperature.

The synthesis of carotenoid in cladocerans and copepods is generally regarded as a way of protecting against the deleterious effects of U.V. radiation (Hairston 1976, Siebeck 1978). In the pond of Differdange, the positive correlation between the carotenoid content of D. magna and water transparency, coupled with the fact that the pond is shallow and that no light refuge would exist, seems to confirm this hypothesis.

The carotenoid levels measured at Differdange are lower than those reported by De Meester \& Beenaerts (1993) from $28 \mathrm{D}$. magna clones (from 250 to $457 \mu \mathrm{g} . \mathrm{g}^{-1}$ (DW)) (Table 1). These differences are certainly due to the difference in algal abundance between our study and theirs. Indeed, zooplankton can not synthesise body carotenoids de novo but needs phytoplankton $\beta$-carotene as precursors for this synthesis (Herring 1968a, b, Castillo et al. 1982). Therefore, a reduced availability of algae lowers the maximum quantity of carotenoids that zooplankton can synthesise. This has been confirmed by Partali et al. (1985) who observed a reduction of the carotenoid content from 237 to $25 \mu \mathrm{g} . \mathrm{g}^{-1}$ (DW) in D. magna when individuals were reared for several generations on a yeast diet alone. However, the dependence of the carotenoid synthesis on the algal availability does not imply that the carotenoid body level and chlorophyll $a$ concentration vary parallely. In the pond of Differdange, the carotenoid concentration reaches minimal values in spite of high chlorophyll $a$ concentration because the need for photoprotection is almost non-existent at this time as the water transparency was low as a consequence of the high algal abundance. Our results must, however, be taken cautiously because the carotenoid content of the algae that were present in the gut of the assayed animals may have biased to a certain extent the estimation of the body carotenoid content of $D$. magna.

The presence of a maximum absorbance between 460 and $466 \mathrm{~nm}$ in D. magna has already been noted by De Meester \& Beenearts (1993). It suggests that echinenone, which has a maximum absorbance at 462 $\mathrm{nm}$ when extracted in ethanol (Davies 1976), could be one of the major carotenoid in D. magna.

Despite a marked seasonal variation in biochemical composition, Daphnia magna developing in the waste stabilisation pond have sufficient levels of proteins and lipids to be used for the nutrition of aquacultured fishes (Macartney 1996, Oberle et al. 1997). Moreover, Daphnia magna has a similar carotenoid content to fish meals used to color salmonid flesh (Simpson 1978) and could thus be used for this purpose. On the other hand, the chitin content of the daphnids is significant and comparable or slightly lower than the current source of chitin for the industry, i.e. crabs and shrimps (Sandford 1989). On the basis of an annual secondary production of $101 \mathrm{~g} \cdot \mathrm{m}^{-3}$.year-1 (Cauchie et al. 1995), the annual chitin production would reach about $5 \mathrm{~g}$ chitin. $\mathrm{m}^{-3}$.year ${ }^{-1}$, that is to say a total chitin production of $690 \mathrm{~kg}^{-y e a r^{-1}}$ for the whole waste stabilisation pond. The chitin production by $D$. magna appears higher than most of other crustaceans, especially as far as marine species are concerned. (Cauchie 1997). The source of chitin studied in the present paper is therefore worth considering for commercial applications. Further chemical characterisation of the chitin isolated from daphnids is, however, needed to complete the evaluation of the prospect of using these crustaceans as a commercial source of chitin.

\section{Acknowledgments}

The authors are grateful to Miss $\mathrm{Cl}$. Toussaint for her excellent technical assistance. The process for the production of crustaceans in aerated sewage pond is patented by the European Patent Office (EP 0277482 B1). Henry-Michel Cauchie has a grant from the Belgian Fund for Research in Industry and Agriculture. Lucien Hoffmann is research assistant of the Belgian National Fund for Scientific Research.

\section{References}

Barnes H. \& Blackstock J. 1973. - Estimation of lipids in marine animals and tissues : detailed investigation of the sulfophosphovanilline method for "total" lipids. J. Exp. Mar. Biol. Ecol., 12 : 103-123.

Berberovic R. 1990. - Elemental composition of two coexisting Daphnia species during the seasonal course of population development in Lake Constance. Oecologia, 84 : 340-350.

Blazka P. 1966. - The ratio of crude protein, glycogen and fat in the individual steps of the production chain, in Hydrobiological Studies I. Z. Hrbacek (Ed.), Academia, Publishing House of the Czechoslovak Academy of Sciences, Prague : 395-409. 
Bligh E.G. \& Dyer W.J. 1959. - A rapid method of total lipid extraction and purification. Can. J. Biochem. Physiol., $37: 911-917$.

Bottrell H.H. 1975. - Generation time, length of life, instar duration and frequency of moulting and their relationship to temperature in eight species of Cladocera from River Thames. Oecologia, $19: 129-140$

Bradford M.M. 1975. - A rapid and sensitive method for the quantification of microgram quantities of protein utilizing the principle of protein-dye binding. Anal. Biochem., $72: 248-254$.

Castillo R., Negres-Sadargues G. \& Lenel R. 1982. - General survey of carotenoids in Crustacea, in Carotenoid Chemistry and Biochemistry. G. Britton \& T.W. Goodwin (Eds), Oxford University Press, London : 211-224.

Cauchie H.M. 1997. - An attempt to estimate crustacean chitin production in the hydrosphere, in Advances in chitin science, volume II. A. Domard, G.A.F. Roberts \& K.M. Varum (Eds), Jacques André Publisher, Lyon : 32-39.

Cauchie H.M., Hoffmann L., Jaspar-Versali M.F., Salvia M. \& Thomé J.P. 1995. - Daphnia magna Straus living in an aerated sewage lagoon as a source of chitin : ecological aspects. Belg. $J$. Zool., $125: 67-78$.

Cauchie H.M., Murugan G., Thomé J.P. \& Dumont H.J. 1997. — Intra- and interspecific variations in the chitin content of some anostracans. Hydrobiologia, $359: 223-228$.

Czeczuga B. 1984. - Investigations of carotenoprotein complexes in animals. XI. Carotenoprotein and carotenoids in Daphnia magna Straus. Pol. Arch. Hydrobiol., 31 : 91-97.

Davies B.H. 1976. - Carotenoids, in Chemistry and Biochemistry of Plants Pigments, Volume 2. T.W. Goodwin (Ed.), Chapman and Hall, London : 138-160.

De Meester L. \& Beenaerts N. 1993. - Heritable variation in carotenoid content in Daphnia magna. Limnol. Oceanogr., 38 : 11931199.

Dinges R. 1973. - Ecology of Daphnia in stabilisation ponds. Texas State Department of Health, Austin, Texas : $150 \mathrm{p}$.

Dor I., Schechter H. \& Bromley H.J. 1987. — Limnology of an hypertrophic reservoir storing waste water effluent for agriculture at Kibbutz Na'an, Israël. Hydrobiologia, $150: 225-241$.

Dumont H.J., Van De Velde I. \& Dumont S. 1975. - The dry weight estimate of biomass in a selection of Cladocera, Copepoda and Rotifera from plankton, periphyton and benthos of continental waters. Oecologia, $19: 75-97$.

Dunn M.J. 1993. - Determination of total protein concentration, in Protein purification methods : a practical approach. E.L. V. Harris \& S. Angol (Eds), IRL Press : 10-18.

Edwards P. \& Pullin R.S.V. (Eds) 1990. - Wastewater-Fed Aquaculture, Proceedings of the International Seminar on Wastewater Reclamation and Reuse for Aquaculture, Calcutta, India, 6-9 December, 1988. Environmental Sanitation Information Center, Asian Institute of Technology, Bangkok, Thailand : $294 \mathrm{p}$.

Elendt B.P. 1989. - Effects of starvation on growth, reproduction, survival and biochemical composition of Daphnia magna. Arch. Hydrobiol., 116 : 415-433.

Farkas T. 1958. - Comparative studies on the chemical composition of lower and higher crustaceans. Ann. Biol. Tihany, 25 : 179-186.

Guisande C., Toja J. \& Mazuelos N. 1991. - The effect of food on protein content in rotifer and cladoceran species : a field correlational study. Freshwat. Biol., $26: 433-438$.

Hairston N.G. Jr. 1976. — Photoprotection by carotenoid pigments in the copepod Diaptomus nevadensis. Proc. Natl. Acad. Sci., 73 : 971-974.

Hathaway C. \& Stefan H. 1995. - Model of Daphnia populations for wastewater stabilisation ponds. Water Res., 29 : 195-208.
Herring P. 1968a. - The carotenoid pigments of Daphnia magna Straus - I. The pigments of animals fed Chlorella pyrenoidosa and pure carotenoids. Comp. Biochem. Physiol., 24 : 187-203.

Herring P. 1968b. - The carotenoid pigments of Daphnia magna Straus - II. Aspects of pigmentary metabolism. Comp. Biochem. Physiol., 24 : 205-221.

Jeuniaux C. 1963. - Chitine et chitinolyse : un chapitre de biologie moléculaire. Masson, Paris : $181 \mathrm{p}$.

Jeuniaux C. 1965. - Chitine et phylogénie : application d'une méthode enzymatique de dosage de la chitine. Bull. Soc. Chim. Biol., 47 : 2267-2278.

Jürgens K. 1994. - Impact of Daphnia on planktonic microbial food webs - A review. Mar. Microb. Food Webs, 8 : 295-324.

Lemcke H.W. \& Lampert W. 1975. — Veränderungen im Gewicht und der chemischen Zusammensetzung von Daphnia pulex im Hunger. Arch. Hydrobiol., Suppl. 48 : 108-137.

Lorenzen C.J. 1967. - Determination of chlorophyll and pheo-pigments: spectrophotometric equations. Limnol. Oceanogr., 12 : 343-353.

Lowry O.H., Rosebrough N.J., Farr A.L. \& Randall R.J. 1951. Protein measurement with the Folin phenol reagent. J. Biol. Chem., 193 : 265-275.

Macartney A. 1996. - Ornemental fish nutrition and feeding, in Manual of companion animal nutrition and feeding. N.C. Kelly \& J.M. Wills (Eds), BSAVA, Shurdington, U.K. : 244-251.

McKee M.J. \& Knowles C.O. 1987. - Levels of protein, RNA, DNA, glycogen and lipid during growth and development of Daphnia magna Straus (Crustacea : Cladocera). Freshwat. Biol., $18: 341-351$.

Muzzarelli R.A.A. 1996. - Chitin, in The polymeric materials encyclopedia. Volume 2. J.C. Salamone (Ed.), CRC Press, Inc., Boca Raton, USA : 1200-1205.

Oberle M., Schwarz F.J. \& Kirchgessner M. 1997. - Growth and carcass quality of carp (Cyprinus carpio L.) fed different cereals, lupin seed or zooplankton. Arch. Anim. Nutr., 50 : 75-86.

Paine R.T. 1971. - The measurement and application of the calorie to ecological problems. Ann. Rev. Ecol. Syst., 2 : 145-164.

Partali V., Olsen Y., Foss P. \& Liaaen-Jensen S. 1985. - Carotenoids in food chain studies - I. Zooplankton (Daphnia magna) response to a unialgal (Scenedesmus acutus) carotenoid diet, to spinach, and to yeast diets supplemented with individual carotenoids. Comp. Biochem. Physiol., 82B : 767-772.

Porter K.G., Feig Y.S. \& Vetter E.F. 1983. - Morphology, flow regimes and filtering rates of Daphnia, Ceriodaphnia and Bosmina fed on natural bacteria. Oecologia, 58 : 156-163.

Reissig J., Strominger J. \& Leloir L. 1955. - A modified colorimetric method for the estimation of $\mathrm{N}$-acetylamino sugars. J. Biol. Chem., 217 : 959-966.

Sandford P.A. 1989. - Chitosan : commercial uses and potential applications, in Chitin and Chitosan, Proceedings of the 4th International Conference on Chitin/Chitosan. G. Skjak-Braek, T. Anthonsen \& P.A. Sandford (Eds), Elsevier Applied Science, London : 51-69.

Schacterle G.R. \& Pollack R.L.1973. - A simplified method for the quantitative assay of small amounts of protein in biological material. Anal. Biochem., $51: 654-655$.

Scopes R.K. 1974. - Measurement of protein by spectroscopy at 205 nm. Anal. Biochem., 59 : 277-282.

Sevrin-Reyssac J. 1992. - Valorisation du lisier de porc par élevage intensif d'algues et de zooplancton. Aqua Revue, $40: 33-43$

Siebeck O. 1978. - Ultraviolet tolerance of planktonic crustaceans. Int. Ver. Theor. Angew. Limnol. Verh., 20 : 2469-2473. 
Simpson K.L. 1978. - The recovery of protein and pigments from shrimp and crab meals and their use in salmonid pigmentation, in Proceedings of the Conference on Chitin/Chitosan. R. A. A. Muzzarelli \& R. E. Pariser (Eds), MIT Sea Grant Program, Massachussets : 253-262.

ter Braak C.F.J. \& Prentice I.C. 1988. - A theory of gradient analysis. Adv. Ecol. Res., 18 : 271-317.

ter Braak C.F.J. \& Smilauer P. - 1998. - CANOCO reference manual and user's guide to Canoco for Wondows : Software for Canonical Community Ordination (version 4). Microcomputer Power, Ithaca, NY, USA : 352 p.

Tessier A.J. \& Goulden C.E. 1982. - Estimating food limitation in cladoceran populations. Limnol. Oceanogr., 27 : 707-717.
Verdonschot P.F.M. \& ter Braak C.J.F. 1994. - An experimental manipulation of oligochaete communities in mesocosms treated with chlorpyrifos or nutrient additions: multivariate analyses with Monte Carlo permutation tests. Hydrobiologia, 278 : 251-266.

Vijverberg J. \& Frank T.H. 1976. - The chemical composition and energy contents of copepods and cladocerans in relation to their size. Freshwat. Biol., $6: 333-345$.

Zagalsky P.F., Cheesman D.F. \& Ceccaldi H.J. 1967. - Studies of carotenoid-containing lipoproteins isolated from the eggs and ovaries of certain marine invertebrates. Comp. Biochem. Physiol., $22: 815-871$ 